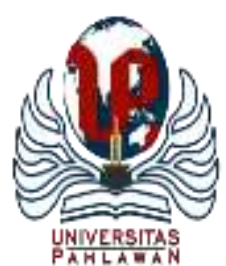

\title{
JURNALBASICEDU
}

Volume 5 Nomor 6 Tahun 2021 Halaman 5386 - 5396

Research \&Learningin Elementary Education

https://jbasic.org/index.php/basicedu

\section{The Role of Imaginative Fairy Tales in Reading Literacy}

\author{
Chandra $^{1 凶}$, M Habibi $^{2}$, Ari Suriani ${ }^{3}$, Annisa Kharisma ${ }^{4}$ \\ Universitas Negeri Padang, Indonesia ${ }^{1,2,3}$, \\ Universitas Pendidikan Indonesia, Indonesia ${ }^{4}$ \\ E-mail: chandra@fip.unp.ac.id ${ }^{1}$, habibie91@fip.unp.ac.id ${ }^{2}$, $\underline{\text { arisuriani@fip.unp.ac.id }}^{3}$, \\ annisakharisma@upi.edu ${ }^{4}$
}

\begin{abstract}
Abstrak
Program Gerakan Literasi Sekolah di Indonesia yang telah dijalankan di sekolah dasar masih minim dengan sumber bacaan yang kekinian, kurang mengajak siswa untuk berpikir kedepan, dan mengembangkan sikap yang monoton. Untuk itu perlu dihasilkan buku-buku bacaan anak terbaru seperti dongeng imajinatif yang menyajikan cerita-cerita yang berkaitan dengan perkembangan teknologi. Menghasilkan dongeng imajinatif adalah tujuan dari penelitian ini. Penelitian dilakukan dengan menggunakan metode campuran dengan model pengembangan Plomp. Model pengembangan Plomp memiliki tiga langkah: tahap penelitian pendahuluan, tahap pembuatan prototipe, dan tahap penilaian. Hasil penelitian pada penelitian pendahuluan bahwa siswa menyukai cerita imajinatif dan membutuhkan cerita baru setiap pagi sebelum pembelajaran dimulai. Pada tahap prototyping dihasilkan sebuah buku dongeng imajinatif yang valid dan praktis. Buku dongeng imajinatif ini dirancang menggunakan program Adobe Photoshop. Buku dongeng imajinatif yang dikembangkan mampu memberikan ide-ide baru bagi siswa yang membacanya. Selain itu, pengembangan sikap positif juga termasuk dalam cerita, sehingga memudahkan guru dalam mendidik siswa di sekolah dasar.
\end{abstract}

Kata Kunci: Dongeng, Literasi Membaca, Imajinatif, Sekolah Dasar, Pendidikan.

\section{Abstract}

The School Literacy Movement program in Indonesia which has been run in elementary schools was still minimal with current reading resources, less inviting students to think ahead, and developing a monotonous attitude. It was necessary to produce the latest children's reading books such as imaginative tales that present stories related to technological developments. Producing imaginative fairy tales was the aim of this research. The study was conducted using a mixed-method with the Plomp development model. The Plomp development model has three steps: preliminary research, prototyping phase, and assessment stage. The research results at the preliminary research that students like imaginative tales and need new stories every morning before learning begins. In the prototyping phase is produced a valid and practical imaginative fairy tale book. Imaginative fairy tale book was designed using the Adobe Photoshop program. The imaginative fairy tale book that was developed was able to provide new ideas for students who read it. Besides, the development of a positive attitude is also included in the story, making it easier for teachers to educate students in elementary school.

Keywords:Fairy Tales, Reading Literacy, Imaginative, Elementary School, Education

Copyright (c) 2021 Chandra, M Habibi, Ari Suriani, Annisa Kharisma

$\checkmark$ Corresponding author :

Email : chandra@fip.unp.ac.id

DOI : $:$ https://doi.org/10.31004/basicedu.v5i6.1516

ISSN 2580-3735 (Media Cetak)

ISSN 2580-1147 (Media Online) 
5387 The Role of Imaginative Fairy Tales in Reading Literacy - Chandra, M Habibi, Ari Suriani, Annisa Kharisma

DOI: https://doi.org/10.31004/basicedu.v5i6.1516

\section{INTRODUCTION}

The latest ranking data according to the World's Most Literate Nations, compiled by Central Connecticut State University in 2016, ranks Indonesia's literacy at 60th out of 61 countries. To improve the literacy skills of Indonesian students, it is necessary to develop innovative and appropriate teaching materials. The participation of instructional materials is the main thing that cannot be separated from the learning process. Therefore, the readiness of teaching materials is a determining factor for the success of the learning process of reading literacy given in elementary school (Habibi et al., 2020; Nurgiyantoro et al., 2020; Rodgers \& Mauck, 2017; Schüller et al., 2017; Taufina \& Chandra, 2017).

Based on the results of the analysis, observation, and interviews with a teacher in class $\mathrm{V}$ in several elementary schools in Padang, there were some problems. First, the teaching material used does not describe the effective reading literacy process, so the School Literacy Movement was rarely carried out according to the reading literacy process that is supposed to be. In the learning process in the classroom, there was also a gap in the reading process carried out, they are pre-reading, reading, and post-reading that have not been fully implemented. Reading learning rarely begins with the process of predicting reading content with student activities asking questions and allowing students answer each other's questions. Post-reading activities that have to apply to learn reading skills were also rarely directed students to discuss the content of reading texts that should have communication between students and the teacher discussing the content of reading texts. This is caused by a lack of availability in teaching materials (Hendrizal \& Chandra, 2018; Inoue et al., 2018; Kalindi et al., 2018; Muhammadi et al., 2018a; Spichtig et al., 2016).

Second, the teaching material for reading comprehension used in the fifth grade of the elementary school still did not bring students to imagine what they are reading because in the teaching materials they did not pay attention to reading comprehension techniques. Most students read by voicing the text they read so that their lips move (Chandra et al., 2019; Cheng, 2014; Puspita \& Rahman, 2017). Another movement was found that students moved their heads following the reading lines when reading comprehension, and pointed at the lines of reading with fingers. This means that the reading comprehension technique was rarely applied by students which cause the level of students' reading comprehension skills to below. Based on the result of a study conducted by PISA (Program for International Student Assessment) in 2006 that Indonesian students' reading skills are still low (Chandra et al., 2018; Habibi et al., 2018). The following are some pictures that show the activity error of students applying the reading comprehension technique (Chandra et al., 2018; Muhammadi et al., 2018b).

Third, the teaching material used was not following the rules in reading literacy. Teaching materials used in the learning process didn't adopt reading comprehensively as a whole. Student reading texts are arranged and pegged to certain materials. The text used was not following the students' world, so students were less interested in reading material and had difficulty in reciting the content of reading texts, so students rarely communicate what they read with their teachers and friends (Habibi \& Chandra, 2018; Hamilton \& Long, 2016). Whereas the collaborative conceptual conversation between the teacher and the students during the reading of the storybook influences the future success of students in interpreting the content of the reading. While there were still students who did not like reading due to the less interesting reading material (Chandra et al., 2018, 2020; Sheriston, 2016; Taufina \& Chandra, 2017).

Fourth, the critical thinking skills of elementary school students were also rarely sustained in the texts and questions provided, so students were accustomed to thinking about what will happen in the story. While the analysis conducted by the researcher about the moral development of elementary school students in Indonesia now is very concerning. Especially the cases of elementary school students who did bullying their classmates in Bukittinggi and Pariaman. Other friends' bully acts also occur in elementary schools which are 
not published on social media. It needs to be felt by education practitioners to fix everything related to the moral development of elementary students (Rainey, 2013).

Based on the explanation above, learning practitioners need to use the Adobe Photoshop program to design an imaginative fairy tale book following the needs of students, so that students can follow the literacy learning process to read appropriately. The right is to choose the right reading text and based on the development and characteristics of students. One type of reading text that can increase students' curiosity about the content of the reading text is reading texts that talk about things that probably happened and never happened before. This is part of imaginative literature. One of the imaginative literatures is fairy tales. A fairy tale is a tale that talks about things that are imaginative about the future that will happen and never happened before. Fairy tales are very good for the development of students' mindsets that familiarizes students to think about the future so that the students' brains are used to thinking about planning what will happen.

\section{METHOD}

Research conducted as a research design that develops a product. Products developed in development research were teaching materials. The development model used in this study is the Plomp development model adopted from the McKenney development model. The Plomp model consists of three stages: (1) preliminary research, (2) prototyping phase, and (3) assessment stage (Plomp \& Nieveen, 2013).

The trial was conducted on a small scale in the Experimental Public Elementary School in Padang City. The trial results are used to find out the practicality and effectiveness of literacy teaching materials to read imaginative tales for grade $\mathrm{V}$ elementary school. The trial to find out the practicality of the product was carried out a trial of students who came from public elementary schools Percobaan for the implementation of the one-to-one evaluation method, small group evaluation, and field test 1 . While the trial to find out the effectiveness of the product was tested in Public Elementary School 15 Ulu Gadut Padang City for the implementation of the field test 2 method.

Types of data obtained from research are qualitative and quantitative data. Qualitative data is obtained from interviews, observations, and field notes. Whereas quantitative data is collected through the results of questionnaires, observation sheets, and anecdotal records.

The data analyzed in the study are validation results data, practicality test results data, and effectiveness test results data. Research data analysis was carried out using descriptive statistical analysis techniques and descriptive techniques. Descriptive statistics for analyzing critical thinking test results, observation sheets, and questionnaires. While descriptive techniques for analyzing interview results.

Validation analysis techniques for teaching materials were carried out to see the validation data of the instructional materials developed. Data obtained from the validation of teaching materials were analyzed for all aspects presented in table form using a Likert scale in the form of values from 1 to 4 .

Data collection instruments used in the study refer to the teaching materials developed, namely in the form of questionnaires, interview guidelines, and observation sheets. All instruments before use were validated by three experts.

\section{RESULTS AND DISCUSSION}

\section{Results}

\section{Results of Student Profile Analysis}

Students tend to prioritize reading to learning activities. The facts found that students tend to open textbooks when in the learning process. Students open books for certain pages if asked by the teacher. 
However, it was also found that students opened books on certain pages to find the information needed during the learning process.

Students can think analytically or have begun to be able to think critically. Critical thinking is shown by students in the learning process in the form of responding to statements in the book. Besides responding to statements in the book, students also respond to the opinions of their friends in the group. It was also found that students responded to what their friends told them in class.

The language used by students has begun to be communicative. When telling a story, the other person can understand the sentence the student is speaking. The words used can make the other person respond to what they say. That is, students can analyze verbal relationships that emphasize the use of logic.

The results of the interviews conducted show that students have the habit of playing bicycles, playing football, playing games, and playing other things. Stories that students like tend to be stories that lead to folklore, fairy tales, and children's stories. Students want stories that have pictures. The image in question is a picture of children and some want pictures of animals. The images presented should also be colored following the original. Interview results are used as guidelines for designing prototypes.

\section{Results of the Preparation of the Initial Draft of the Imaginary Fairy Tale Book}

Characteristics of instructional materials designed contain a presentation of reading texts that build moral values and trigger critical thinking of students. The reading text in question is to produce imaginative fables that relate to the elements of technology, classical elements, and the world of children. The development of teaching materials refers to technical instructions for the development of teaching materials determined by the Ministry of National Education of the Directorate General of Primary and Secondary Education in 2010.

The cover design contains the identity/title of the book designed using the Adobe Photoshop program. This is stated as aiming to provide information about the description of the contents of the teaching material. The inner cover design is sketchy on the teaching material containing a student identity column that is useful for showing ownership identity of the teaching material. Initially, the image design was made manually, then made in the Adobe Photoshop program. The cover design uses various colors. The image presented contains images that represent the contents of the book.

The preface is made to communicate to students the researchers' gratitude and the purpose of the researcher in making teaching materials. The preface is made not too formal so that there is a closeness with students. The preface contains motivational sentences, so students are motivated to learn. The preface also provides a brief description of the purpose of the instructional material designed. Meanwhile, for exposure to the contents of the introductory word using a type of Comic Sans MS with a size of 12 .

Exposure or presentation of imaginative fairy tales is compiled as many as 20 stories. Each story depicts the climax of imaginative fairy tales. Images are presented at the beginning of the story. This has been adjusted to the reading literacy component used, namely: moral development and critical thinking. The color design has also been adjusted to the color gradations in each image. One of the designs for presenting imaginative fairy tales that have been designed can be seen in Figure 1 below. 


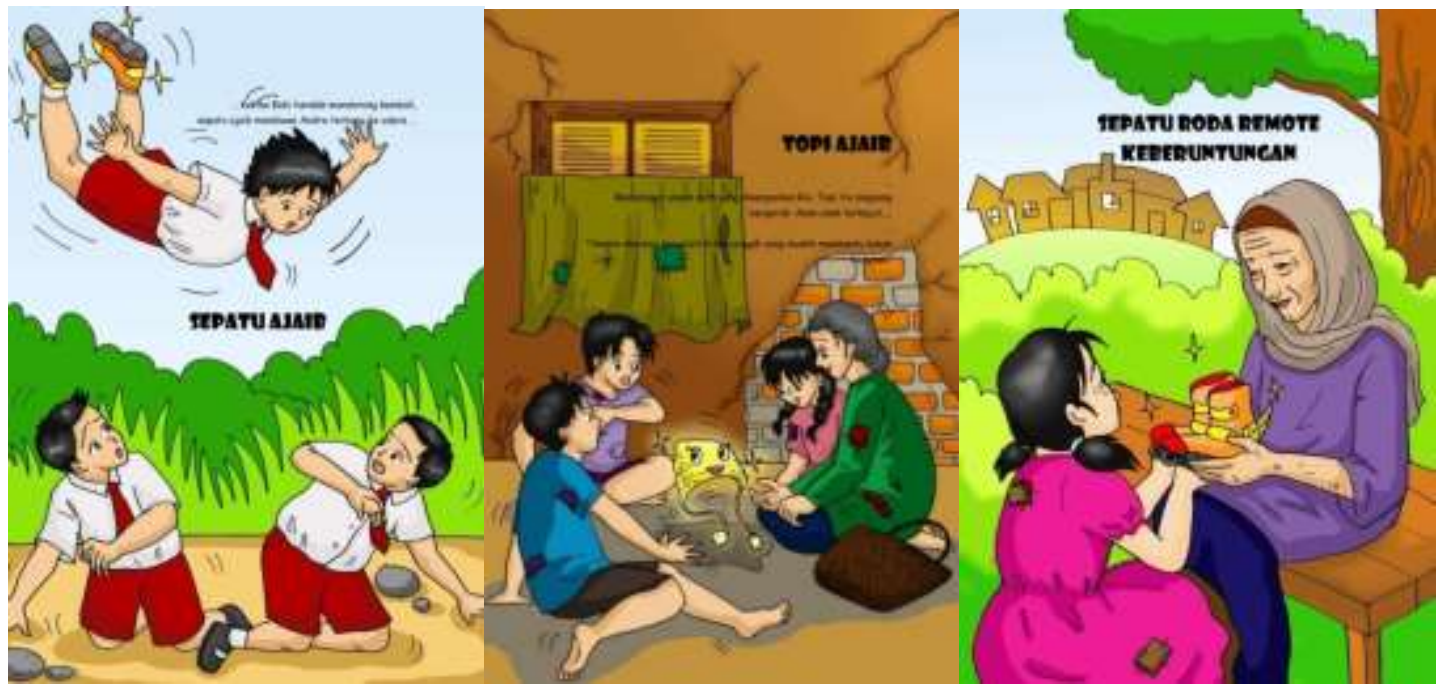

Figure 1 Presentation of Imaginative Fairy Tales

\section{Results Validation of Prototype Design Imaginative Fairytale Book with the Adobe Photoshop Program}

Exposure which became the focal point about prototype 1 is the result of prototype evaluation with the expert review evaluation method. Activities carried out in the prototype evaluation process with the method of expert review evaluation in the form of validation of imaginative fairy book design based on reading literacy. Validation was carried out by 3 experts, namely Padang State University lecturers. Validation of teaching materials is carried out on several aspects, namely aspects of content, linguistic, presentation, and graphic aspects of feasibility. The aspect feasibility of the content consists of five parts: (1) Suitability imaginative fairy book design with student development. (2) Reading literacy teaching materials. (3) The order of material in teaching materials is following the logical learning path and there is moral development. (4) Teaching materials provide opportunities for students in critical thinking. (5) Teaching materials fulfill the characteristics of imaginative fables.

Fundamental changes to imaginative fairytale teaching materials contain elements of reading literacy based on the results of validation, namely the making of interesting titles and story elements in each picture. Based on the description of the validation results from the various aspects above, the overall results of the validation of the imaginative fairy tale books on reading literacy elements can be seen in Table 1.

Table 1 Results of Validation of the Imaginary Fairy Tale Book of Integrity Aspect

\begin{tabular}{clcc}
\hline No. & Aspects Observed & Value & Category \\
\hline 1. & Content Aspects & 3,83 & Very Valid \\
\hline 2. & Linguistic Aspects & 3,40 & Valid \\
\hline 3. & Integrity Aspects & 3,63 & Very Valid \\
\hline & Average & 3,62 & Very Valid \\
\hline
\end{tabular}

Based on Table 1 it can be seen that imaginative fairy tales seen from the feasibility side of the contents have been declared feasible, the language used was following the characteristics of students, and written graphics have used gradations of color, picture, and size to suit students' needs. This means that imaginative fairy tales contain elements of reading literacy that has been declared valid and useless to be tested in elementary school.

\section{Prototype Evaluation Results in Imaginary Fairy Tale Book with One-to-One Evaluation Method}

One-to-one evaluation is carried out on prototypes 1 . The results of the one-to-one evaluation are revised according to the findings. Data is strengthened by student comments. One-to-one evaluation is done 
by giving an imaginative fairy tale (prototype 1) to 1 student. Students who do one-to-one evaluations are sitting in 4th grade at Kuranji State Elementary School 46, Padang City. Students are set as a sample one-toone evaluation due to having the ability in the middle range in their class, which is ranked 12 out of 26 students. Students are asked to read reading literacy materials (imaginative fairy tales) according to their abilities. Students are very interested in the story contained in the book. Students can repeat the contents of the story they read.

\section{Prototype Evaluation Result in Imaginary Fairy Tale Book with Small Group Evaluation Method}

The small group test was conducted by providing revised teaching materials from the one-to-one evaluation method on five students of grade IV-B SD 06 Padang Besi, Lubuk Kilangan Subdistrict, Padang City. The five students were asked to read imaginative fairy tales containing elements of reading literacy following their abilities. Students seemed enthusiastic about receiving imaginative fairy tales containing elements of reading literacy. They flipped through pages of teaching materials, after which they immediately read stories in imaginative fairy tales containing elements of reading literacy.

The practicality test activity with the small group evaluation method was ended by asking students to fill out the questionnaire and be interviewed to see the students' responses to the imaginative fairy tales used by them. This is used to see the practicality of teaching materials.

\section{Prototype Evaluation Results Imaginary Fairy Tale Book With Field Test Evaluation 1 Method}

Field test evaluation method 1 was carried out in Class IV-A of SD Negeri 06 Padang Besi, District of Lubuk Kilangan, City of Padang. Next, the teacher questionnaire and student questionnaire were distributed. Practicality questionnaires are distributed, including questionnaire responses from students and questionnaires to students' responses to the use of imaginative fairy tales that have been implemented.

A practicality questionnaire was also given to students of SD Negeri 06 Padang Besi, Lubuk Kilangan Subdistrict, totaling 22 people. The questionnaire is given after learning using imaginative fairy tales books. The results of data analysis on the student response questionnaire on the practicality of imaginative fairy tale books can be seen in table 2 .

Questionnaires of students' responses to the practicality of imaginative fairy tale books were also given to students in grades IV-B of SD Negeri 06 Padang Besi, Lubuk Kilangan Subdistrict, Padang City, totaling 22 people. This questionnaire was given after learning using imaginative fairy tales books. Based on the results of data analysis on student response questionnaires on the practicality of imaginative fairy tales in Table 5 it can be seen that most students like the look of the given book. Students like the colors used in the book so they feel happy following the process of the School Literacy Movement and the learning process by using imaginative fairy tales.

Students' interest in imaginative fairy tales is also caused because the stories used are not so far from the real-life of students in everyday life. Imaginative fairy tales help students understand more about science in books because they are equipped with images that match the contents of the book, so that students feel easily understand the contents of the book. The contents of the book also invite students to think critically about contemporary technology. Student imagination runs by itself and he can retell the imaginative fairy tales he reads. Besides, students are educated to have good morals following the stories in the book. Students are directed by bringing moral education in imaginative fairy books to be applied in everyday life.

Table 2Results of Questionnaire Evaluation of Student Response to Prototype of Imaginary Fairy Tale Book with Field Test Evaluation Method

\begin{tabular}{clcc}
\hline No & \multicolumn{1}{c}{ Aspects Observed } & Value & Category \\
\hline 1. & I like the look of the book given & 97,73 & Very practical \\
\hline 2. & I like the colors in books & 97,73 & Very practical \\
\hline
\end{tabular}


5392 The Role of Imaginative Fairy Tales in Reading Literacy - Chandra, M Habibi, Ari Suriani, Annisa Kharisma

DOI: https://doi.org/10.31004/basicedu.v5i6.1516

\begin{tabular}{llcc}
\hline 3. & I feel happy participating in learning using books & 100 & Very practical \\
\hline 4. & $\begin{array}{l}\text { I am interested because the contents of the story are } \\
\text { related to real life }\end{array}$ & 95,45 & Very practical \\
\hline 5. & I easily understand the instructions in the book & 92,05 & Very practical \\
\hline 6. & $\begin{array}{l}\text { I am increasingly understanding about science in books } \\
\text { because it is coupled with pictures }\end{array}$ & 90,91 & Very practical \\
\hline 7. & $\begin{array}{l}\text { I actively participate in the use of books so learning } \\
\text { activities increase }\end{array}$ & 96,59 & Very practical \\
\hline 8. & I easily understand the contents of the story in the book & 94,32 & Very practical \\
\hline 9. & I was trained to think about new technology & 92,05 & Very practical \\
\hline 10. & I told the contents of the story what I read & 93,18 & Very practical \\
\hline 11. & I was led by how to read silently & 97,73 & Very practical \\
\hline 12. & I was educated to have a good attitude according to the & 95,45 & Very practical \\
\hline story in the book & $\begin{array}{l}\text { I was directed to think more deeply about the purpose of } \\
\text { the story }\end{array}$ & 92,05 & Very practical \\
\hline 14. & I easily understand the story & 94,32 & Very practical \\
\hline 15. & I read the story in the book according to the time set & 96,59 & Very practical \\
\hline 16. & I was allowed to tell a story I read and understood & 95,45 & Very practical \\
\hline & $\quad$ Average & 95,10 & Very practical \\
\hline
\end{tabular}

\section{Discussion}

The development of an imaginative fairy tale book with design adobe photoshop program contains elements of reading literacy by adopting the Plomp development model that has been successfully implemented well. The imaginative fairy tale book contains elements of reading literacy that has been tested on students from state elementary school 46 Kuranji Kuranji District for prototype testing with one-to-one evaluation method, SD Negeri 06 Padang Besi District of Lubuk Kilangan for prototype testing with small group evaluation method and field test evaluation 1.

\section{Validation of Imaginary Fairytale Books}

Validation is needed to test a study. The word "valid" is often interpreted correctly, valid; the word validity can be interpreted as accuracy, truth, and validity. Teaching materials that have been developed are said to be valid if they meet certain criteria. The criteria of characteristics of the product are said to be valid if there is a reflection of knowledge (state of the art knowledge) (Plomp \& Nieveen, 2013). This is what is said with content validation (content validity). Furthermore, the product components must be consistent with each other (construct validity). Therefore, the validation carried out on imaginative fairy tale books containing elements of reading literacy emphasizes the content validity and construct validity in the research conducted (Schiefele, 2016; Taufina et al., 2019).

Content validation has been declared valid by the validator because imaginative fairy tale books contain elements of reading literacy that has been developed following actual needs in elementary school and following the demands of real reading literacy (Banat \& Pierewan, 2019; Shum et al., 2016). The validity of the construct has also been declared valid by the validator. This is because the construct of an imaginative fairy-tale book contains elements of reading literacy that has been developed that meet the terms and conditions of the preparation of teaching materials. Based on the analysis of validation assessment data by validators, an imaginative fairy tale book containing elements of reading literacy developed is considered very valid. The following is explained clearly the description of an imaginative fairy tale book containing elements of reading literacy that has been developed. 
Based on the results of the analysis of the imaginative fairy tale book data containing elements of reading literacy obtained an average value of 3.82. When viewed from the categories that have been established, imaginative fairy tale books contain elements of reading literacy that has been developed classified as very valid categories. Therefore, it can be concluded that imaginative fairy tale books contain elements of reading literacy that is developed following the demands of the characteristics and needs of students (Chandra et al., 2020; Cross- \& Capps, 2012; Kurnia et al., 2018). The presentation of the material is following the indicators formulated and following the development of students.

The content of teaching materials has also been following the demands of reading literacy in elementary school. Various concepts and elaboration of the tasks contained in imaginative fairy tale books containing elements of reading literacy make it easier for students to understand the content of the reading appropriately. Besides, the use of language in teaching materials uses simple and clearer sentences, so that it is easily understood by every student. Sentence after sentence uses the right spelling (Hamilton \& Long, 2016). The imaginative fairy tale book contains elements of developed reading literacy designed with attractive color gradations, to motivate students to follow the learning process well. Thus, it can be concluded that an imaginative fairy tale book containing elements of reading literacy developed has been declared valid and can be used in the School Literacy Movement Program.

\section{The Practicality of Imaginative Fairy Tale Books}

Good teaching materials, not only meet the validity criteria. However, good teaching materials must also be practical. The practicality level is useful for the achievement of the teacher and students in using imaginative fairy tale books that contain elements of literacy reading well in learning. The teaching material was said to be practical if the teaching material can be used easily by teachers and students in the learning process. To see whether imaginative fairy tales contain elements of reading literacy that have been developed practically or not? The trial was conducted on students of SD Negeri 46 Kuranji, Kuranji District and SD Negeri 06 Padang Besi, Lubuk Kilangan Subdistrict, Padang City.

The results of the analysis of student response questionnaires show that students become easier to understand the contents of the reading as a whole. The imaginative fairy tale book contains elements of reading literacy that is developed as well as interesting for students because it is designed with more interesting color gradations and adapted to the characteristics of student development (Collins \& Madigan, 2017). This can be seen from the results of student responses stating that imaginative fairy tales contain elements of reading literacy that is used practically used in the learning process.

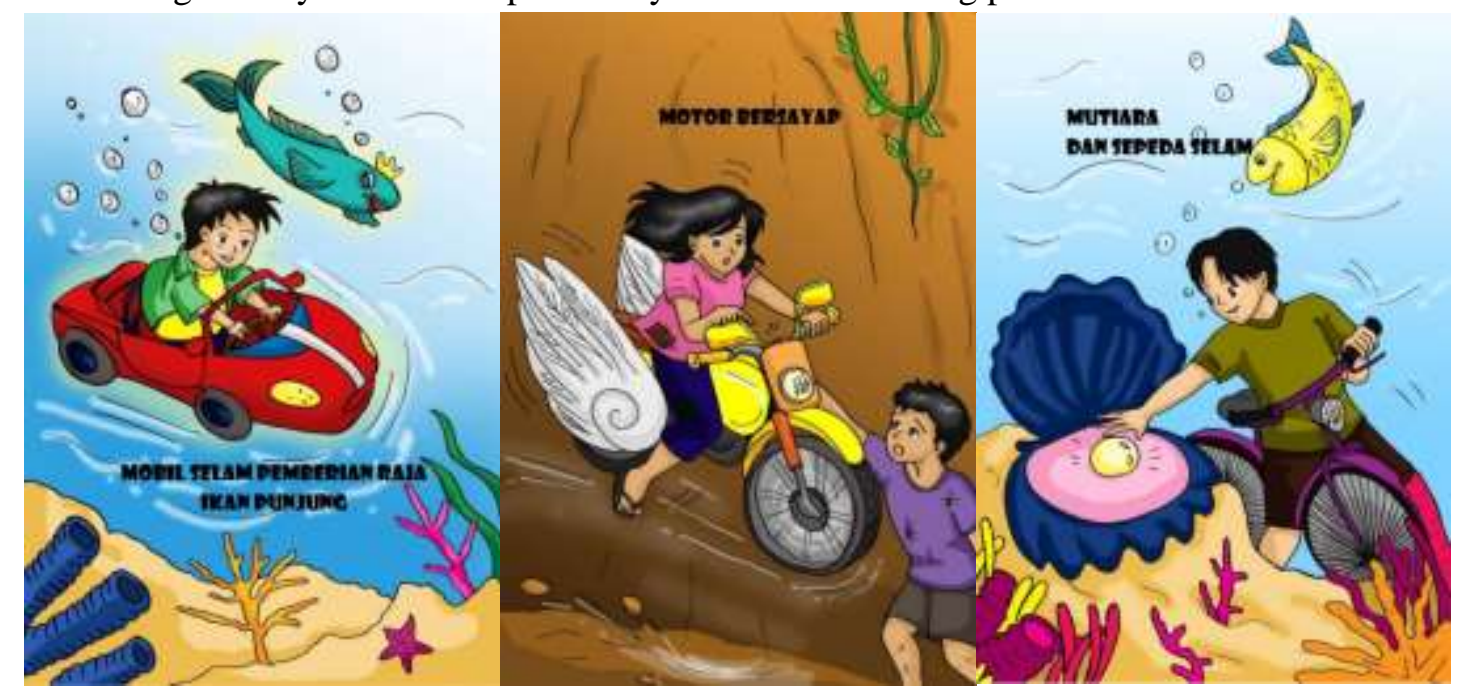

Figure 2 One of Illustration of Imaginary Fairy Tale 
5394 The Role of Imaginative Fairy Tales in Reading Literacy - Chandra, M Habibi, Ari Suriani, Annisa Kharisma

DOI: https://doi.org/10.31004/basicedu.v5i6.1516

Students argue that the legibility of imaginative fairy tales contains elements of literacy that are clear and easy to understand. This means that students are very helpful in understanding the content of reading in full through the stages of the learning process presented in an imaginative fairy tale book containing elements of reading literacy (Tompkins et al., 2017). The following are some examples of imaginative fairy tale picture designs that contain elements of reading literacy.

\section{CONCLUSIONS}

Based on the development of imaginative fairy tale books that contain elements of reading literacy that has been carried out, it can be concluded that research produces imaginative fairy tale books containing elements of literacy reading are very valid and very practical categories with the Adobe Photoshop program design. This can be seen based on the results of the validation of imaginative fairy tale books containing elements of literacy reading by expert validators that have been carried out. This gives an illustration that imaginative fairy tale books contain elements of reading literacy that has been developed valid and partisan so that they can be used in the School Literacy Movement Program.

\section{ACKNOWLEDGMENTS}

The research team would like to thank Universitas Negeri Padang for funding the research for one year.

\section{REFERENCES}

Banat, S. M., \& Pierewan, A. C. (2019). Reading Literacy And Metacognitive Strategy For Predicting Academic Achievement. Litera, 18(3). Https://Doi.Org/10.21831/Ltr.V18i3.24806

Chandra, C., Arief, D., Kharisma, A., Habibi, M., \& Suriani, A. (2020). Writing Literacy As An Effort To Build Positive Character Of Elementary School Students. Jurnal Pajar (Pendidikan Dan Pengajaran), 4(1). Https://Doi.Org/10.33578/Pjr.V4i1.7863

Chandra, C., Rahman, R., Hartati, N., Kharisma, A., Fauziah, M., \& Wismaliya, R. (2019). Early Reading And Writing By Using The Manakok Game As A Manifestation Of Basic Literacy. Https://Doi.Org/10.4108/Eai.29-8-2019.2288919

Chandra, Mayarnimar, \& Habibi, M. (2018). Keterampilan Membaca Dan Menulis Permulaan Menggunakan Model Vark Untuk Siswa Sekolah Dasar. Jurnal Inovasi Pendidikan Dan Pembelajaran Sekolah Dasar, 2(1), 72-80. Https://Doi.Org/Https://Doi.Org/10.24036/0201821100050-0-00011

Cheng, Y. (2014). Growth Of Compounding Awareness Predicts Reading Comprehension In Young Chinese Students : A Longitudinal. 91-104. Https://Doi.Org/10.1002/Rrq.155

Collins, J. L., \& Madigan, T. P. (2017). Bringing Together Reading And Writing : An Experimental Study Of Writing. 311-332. Https://Doi.Org/10.1002/Rrq.175

Cross-, R. P. A., \& Capps, M. (2012). U.S. And Chilean College Students' Reading Practices: A Cross-Cultural Perspective. 455-471. Https://Doi.Org/10.1002/Rrq.144

Habibi, M., \& Chandra. (2018). Strategi Direct Writing Activity Sebagai Upaya Peningkatan Keterampilan Menulis Deskripsi Bagi Siswa Kelas Ii Sd. Jurnal Inovasi Pendidikan Dan Pembelajaran Sekolah Dasar, 2(1). Http://E-Journal.Unp.Ac.Id/Index.Php/Jippsd

Habibi, M., Chandra, C., Mahyuddin, R., \& Hendri, S. (2018). Validity Of Teaching Materials For Writing Poetry Based On Creative Techniques In Elementary Schools. Mimbar Sekolah Dasar, 5(3), 145. Https://Doi.Org/10.17509/Mimbar-Sd.V5i3.14501 
5395 The Role of Imaginative Fairy Tales in Reading Literacy - Chandra, M Habibi, Ari Suriani, Annisa Kharisma

DOI: https://doi.org/10.31004/basicedu.v5i6.1516

Habibi, M., Sukma, E., Chandra, C., Suriani, A., \& Fadillah, N. (2020). Models Of Literacy Media In Improving Reading Skill Of Early Grade Students. Https://Doi.Org/10.4108/Eai.11-12-2019.2290809

Hamilton, S., \& Long, D. L. (2016). Inference Generation During Reading. 1-12. Https://Doi.Org/10.1002/Rrq.148

Hendrizal, \& Chandra. (2018). Preliminary Research Description In Developing Tematics Learning Materials By Using Character Building And Discovery Learning To Establish Children Aged 6-9 Years. International Conference Of Early Childhood Education, 169, 95-101. Https://Www.AtlantisPress.Com/Proceedings/Icece-17/25889741

Inoue, T., Georgiou, G. K., Parrila, R., \& Kirby, J. R. (2018). Examining An Extended Home Literacy Model : The Mediating Roles Of Emergent Literacy Skills And Reading Fluency. Scientific Studies Of Reading, OO(00), 1-16. Https://Doi.Org/10.1080/10888438.2018.1435663

Kalindi, S. C., Mcbride, C., \& Dan, L. (2018). Early Literacy Among Zambian Second Graders: The Role Of Adult Mediation Of Word Writing In Bemba. Reading Research Quarterly, 53(1), 7-27. Https://Doi.Org/10.1002/Rrq.180

Kurnia, R., Arief, D., \& Irdamurni, I. (2018). Development Of Teaching Material For Narrative Writing Using Graphic Organizer Story Map In Elementary School. International Journal Of Research In Counseling And Education, 1(1), 22. Https://Doi.Org/10.24036/009za0002

Muhammadi, Taufina, \& Chandra. (2018a). Literasi Membaca Untuk Memantapkan Nilai Sosial Siswa Sd. Litera, 17(2), 202-212. Https://Doi.Org/Http://Dx.Doi.Org/10.21831/Ltr.V17i2.16830

Muhammadi, Taufina, \& Chandra. (2018b). Literasi Membaca Untuk Memantapkan Sosial Siswa Sekolah Dasar. Litera, 17(2), 202-212. Https://Doi.Org/Http://Dx.Doi.Org/10.21831/Ltr.V17i2.16830

Nurgiyantoro, B., Lestyarini, B., \& Rahayu, D. H. (2020). Konstruk Asesmen Literasi Fungsional Untuk Siswa Sekolah Menengah Pertama. Litera, 19(2). Https://Doi.Org/10.21831/Ltr.V19i2.32977

Plomp, \& Nieveen. (2013). An Introduction To Educational Design Research.

Puspita, R. D., \& Rahman. (2017). A Meningkatkan Kemampuan Membaca Pemahaman Berbantuan Pembelajaran Tematik Terpadu Bernuansa Model Interactive-Compensatory. Pendas: Jurnal Ilmiah Pendidikan Dasar, 2(2), 200-211. Https://Doi.Org/Http://Dx.Doi.Org/10.23969/Jp.V2i2.557

Rainey, E. C. (2013). Disciplinary Literacy In English Language Arts : Exploring The Social Reading And Reasoning. 1-19. Https://Doi.Org/10.1002/Rrq.154

Rodgers, E., \& Mauck, S. (2017). Of The Observation Survey Of Early Literacy Achievement. O(0), 1-19. Https://Doi.Org/10.1002/Rrq.181

Schiefele, U. (2016). Factorial And Construct Validity Of A New Instrument For The Assessment Of Reading Motivation. 221-237. Https://Doi.Org/10.1002/Rrq.134

Schüller, E. M., Birnbaum, L., \& Kröner, S. (2017). What Makes Elementary School Students Read In Their Leisure Time? Development Of A Comprehensive Questionnaire. Reading Research Quarterly, 52(2), 161-175. Https://Doi.Org/10.1002/Rrq.164

Sheriston, L. (2016). Routes To Reading And Spelling: Testing Route Theory. Reading Horizons, 1-15. Https://Doi.Org/10.1002/Rrq.143

Shum, K. K., Ho, C. S., \& Siegel, L. S. (2016). First--Language Longitudinal Predictors Of Second-Language Literacy In Young L2 Learners. 51(3), 323-344. Https://Doi.Org/10.1002/Rrq.139

Spichtig, A. N., Hiebert, E. H., Pascoe, J. P., \& Pearson, P. D. (2016). Based Silent Reading Efficiency In The United States : A Comparison Of Current Data With Performance In 1960. Reading Research Quarterly, 51(2), 239-259. Https://Doi.Org/10.1002/Rrq.137

Taufina, \& Chandra. (2017). Developing The Big Questions And Bookmark Organizers (Bqbo) StrategyBased Reading Literacy Learning Materials In The 4th Grade Of Elementary School. International 
5396 The Role of Imaginative Fairy Tales in Reading Literacy - Chandra, M Habibi, Ari Suriani, Annisa Kharisma

DOI: https://doi.org/10.31004/basicedu.v5i6.1516

Conference For Science Educators And Teachers, 118(5), 857-864. Https://Www.AtlantisPress.Com/Proceedings/Icset-17/25886637

Taufina, Chandra, \& Kharisma, A. (2019). Technology Integration In Thematic Learning To Welcome The Era Of The Industrial Revolution 4 . 0 In Elementary Schools. Proceeding Internasional Seminar Of Primary Education, 2, 10-19. Https://Doi.Org/Https://Doi.Org/10.24114/Esjpgsd.V9i1.14297

Tompkins, V., Bengochea, A., \& Justice, L. M. (2017). Maternal Inferential Input And Children's Language Skills. 1-20. Https://Doi.Org/10.1002/Rrq.176 